\title{
COMPARISON OF R/C BUILDINGS WITH A SOFT-STOREY IRREGULARITY WITH RESPECT TO VARIOUS NATIONAL BUILDING CODES
}

\author{
PRIMERJAVA NEPRAVILNOSTI NA VEČNADSTROPNIH \\ BETONSKIH ZGRADBAH GLEDE NA RAZLIČNE NACIONALNE \\ GRADBENE PREDPISE
}

\author{
Mahmud Sami Donduren, Abdulhamit Nakipoglu \\ Selcuk University, Faculty of Engineering, Department of Civil Engineering, 42130 Konya, Turkey \\ sdonduren@selcuk.edu.tr \\ Prejem rokopisa - received: 2018-02-02; sprejem za objavo - accepted for publication: 2018-03-22
}

\author{
doi:10.17222/mit.2018.015
}

\begin{abstract}
In the design of earthquake-resistant reinforced-concrete structural systems, the necessity to construct a regular structure is one of the main principles. Building irregularities generally become obvious with the effect of a seismic load. It is crucial that the irregularities of structural systems should be considered properly with respect to the conditions determined by the building codes. In this study, the soft-storey irregularity that causes most of the losses and damage in earthquakes was investigated with respect to the criterions of various national building codes. Eleven sub-models were produced on the basis of a general building model, and they were analyzed with respect to the conditions of the codes relating to the soft-storey phenomenon using the SAP 2000 structural-analysis program. The first-storey heights of the models were different from each other while all the other parameters and the geometries were the same. In this way, the codes were compared in terms of the effect of the storey height on the formation of a soft storey. Eventually, it was observed that, especially in the Japanese Seismic Code, the soft-storey irregularity is handled very sensibly and safely.

Keywords: earthquake, irregularities, codes, soft storey, SAP (structural-analysis program) 2000
\end{abstract}

Konstruiranje betonsko ojačanih struktur oz. zgradb, odpornih proti potresom, zahteva upoštevanje nekaterih glavnih principov, med katere spada tudi obvezna gradnja pravilne oz. simetrične strukture. Negativne posledice nepravilnosti v zgradbah se pojavljajo predvsem zaradi učinkov seizmičnih bremen. Najbolj pomembno je, da se nepravilnosti na strukturnih sistemih ocenjujejo na ustrezen način glede na stanje, ugotovljeno s pomočjo gradbenih predpisov. V pričujoči študiji avtorji raziskujejo napake na večnadstropnih zgradbah (angl.: soft-storey buildings), ki povzročajo večino izgub in poškodb zaradi potresa, ter jih primerjajo s kriteriji različnih nacionalnih gradbenih predpisov. Na osnovi splošnega gradbenega modela so pripravili enajst (11) podmodelov in jih analizirali s pomočjo programa za analizo struktur SAP 2000 glede na pogoje, podane s predpisi o večnadstropnih zgradbah (soft-storey buildings). V modelih so izbirali različno višino prvega nadstropja, vsi drugi parametri in geometrija zgradb pa je ostala enaka. Na ta način so lahko medsebojno primerjali predpise glede na vpliv višine nadstropja na zgradbo. Na koncu ugotavljajo, da so še posebej japonski seizmični predpisi, ki zagotavljajo varnost večnadstropnih zgradb pred potresi, najboljši v smislu občutljivosti in varnosti le-teh.

Ključne besede: potres, nepravilnosti, kode (predpisi), več nadstropne zgradbe, program za analizo struktur - SAP 2000

\section{INTRODUCTION}

As we all know, a large part of the world is located along seismic belts. Therefore, the importance of the accuracy of a seismic analysis is very crucial in civilengineering structural projects. If we think that a building can be subjected to a seismic load in its lifetime, it becomes crucial that the R/C structural system should be created with the utmost engineering accuracy. An earthquake can be described as a failure of the Earth's crust at a significant depth, effecting the crust's tension. The magnitude of an earthquake indicates the level of the failure, thereby also indicating the amount of the released energy. ${ }^{1}$

Regular structural systems are practical, economical and, most importantly, safe with respect to the structural analysis, application, dimensioning, etc. The buildings that need to be avoided during design and construction work due to the risks regarding their seismic behavior are described as irregular buildings by the seismic codes. Interstorey-rigidity irregularity or, in other words, a soft storey is a vertical structural irregularity, which causes the most significant loss and damage among all the structural irregularities. So, we need to pay a lot of attention to this irregularity when designing a structure. ${ }^{2}$

The irregularity conditions from different codes differ from each other with respect to analyses, calculations and/or approaches., ${ }^{3,4}$ These differences between the codes are the results of the seismicity and different soil conditions of a country or region where the code is used. ${ }^{5}$ Similar studies were conducted by other researchers. $^{6-9}$

In this study, various national building codes were compared regarding the structural-system irregularities to reveal the differences. 


\subsection{Soft storey (interstorey-rigidity irregularity)}

A soft storey is a phenomenon indicating that a storey's rigidity is higher or much lower than that of the storey above or below. In this case, abrupt changes in the amount of relative storey displacements of the adjacent storeys occur. Thereby, the storey that has less rigidity and more displacements is defined as a soft storey. The existence of a soft storey in a building can cause great damage as shown in Figure 1.

The most important reasons of the formation of the soft-storey phenomenon are:

- The building's first-storey height is much greater than the second-storey height (or the height of any storey is much greater than that of the storey above).

- The first storey has very few or no infill walls in comparison to the second storey.

\section{ANALYTICAL PART}

When comparing the building codes, the best results were obtained with the help of analytical calculations. In this stage, one of the most critical irregularities, the soft storey, was handled with the SAP2000 program. The criterions for a soft storey in the Turkish Seismic Code (TSC 2007), American Code of Minimum Design Loads for Buildings and Other Structures (ASCE 7-2002), Indian Seismic Code (IS 1893-1, 2002) and Japanese Building Code were taken into consideration. The calculation methods of these codes were compared. Within this scope, a building model, which was symmetrical with respect to the plan dimensions, was converted into several sub-models, based on the condition that all the parameters were the same and constant except for the changes in the height of the first storey. The main objective was to obtain the limit values of these codes regarding the soft-storey issue by changing the model's first-storey height to form a soft storey. The heights, which result in a soft storey, were compared and the data obtained with analytical calculations allowed a comparison of the storey-irregularitiy criterions included in different codes.
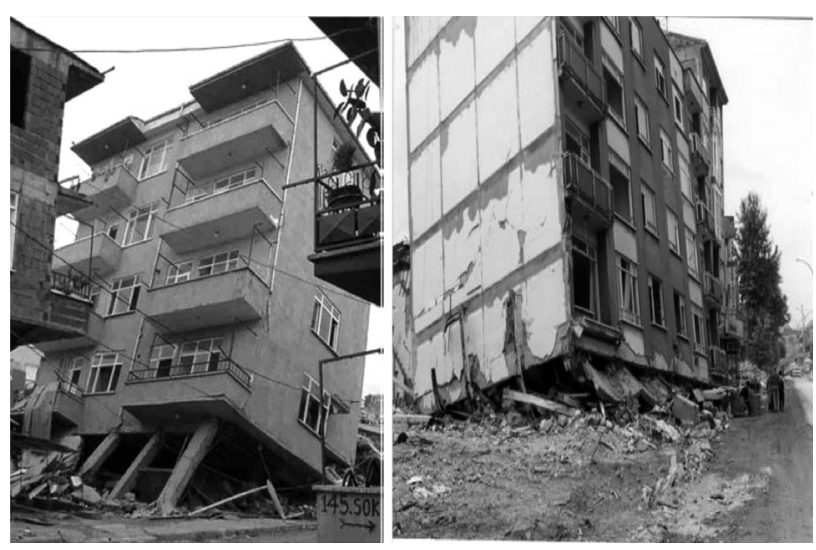
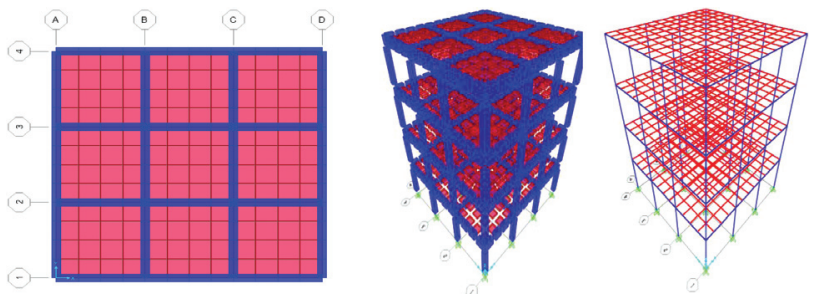

Figure 2: General model's plan and 3D views

\subsection{Information about the model}

The general model is an $\mathrm{R} / \mathrm{C}$ frame system with columns and beams. The plan and 3D views of the model are given in Figure 2.

The parameters used in the analyses are given in Table 1.

Table 1: Parameters of the general model

\begin{tabular}{|c|c|}
\hline $\begin{array}{l}\text { Type of buiding's structural } \\
\text { system: }\end{array}$ & $\begin{array}{l}\text { Frame with beams and } \\
\text { columns }\end{array}$ \\
\hline Total distance in the $\mathrm{x}$ direction: & $9 \mathrm{~m}$ \\
\hline Total distance in the y direction: & $9 \mathrm{~m}$ \\
\hline Span length between the axes: & $3 \mathrm{~m}$ \\
\hline Storey heights: & $3 \mathrm{~m}$ \\
\hline First-storey height: & $h=3 \mathrm{~m}$ (changes) \\
\hline Number of storeys: & 4 \\
\hline Total building height: & 12-14 m (changes) \\
\hline Seismic zone: & $\begin{array}{c}\text { 1.seismic zone (most } \\
\text { severe) }\end{array}$ \\
\hline Soil class: & Z3 (medium firm) \\
\hline Building importance factor: & $I=1$ \\
\hline Response-reduction factor: & $R=8$ \\
\hline Concrete strength: & C25 (25 MPa compressive \\
\hline Rebar strength: & $\begin{array}{c}\text { S420 (420 MPa yield } \\
\text { strength) }\end{array}$ \\
\hline Column dimensions: & $30 \mathrm{~cm} \times 30 \mathrm{~cm}$ \\
\hline Beam dimensions: & $30 \mathrm{~cm} \times 50 \mathrm{~cm}$ \\
\hline Slab thickness: & $15 \mathrm{~cm}$ \\
\hline Beam loads: & $G=6 \mathrm{kN} / \mathrm{m}$ \\
\hline Slab loads: & $G=1.5 \mathrm{kN} / \mathrm{m}^{2}, Q=2$ \\
\hline Seismic load: & $\begin{array}{l}1999 \text { Düzce earthquake, } \\
\text { east-west direction (time } \\
\text { history) }\end{array}$ \\
\hline
\end{tabular}

The first-storey heights of the models are given in Table 2.

Table 2: First storey heights of the models

\begin{tabular}{|c|c|c|c|}
\hline Model number & $\begin{array}{c}\text { First storey } \\
\text { height }\end{array}$ & Model number & $\begin{array}{c}\text { First storey } \\
\text { height }\end{array}$ \\
\hline 1 & $3.00 \mathrm{~m}$ & 7 & $4.30 \mathrm{~m}$ \\
\hline 2 & $3.30 \mathrm{~m}$ & 8 & $4.35 \mathrm{~m}$ \\
\hline 3 & $3.70 \mathrm{~m}$ & 9 & $4.40 \mathrm{~m}$ \\
\hline 4 & $3.85 \mathrm{~m}$ & 10 & $4.50 \mathrm{~m}$ \\
\hline 5 & $4.00 \mathrm{~m}$ & 11 & $5.00 \mathrm{~m}$ \\
\hline 6 & $4.25 \mathrm{~m}$ & - & - \\
\hline
\end{tabular}

Figure 1: Soft-storey damage ${ }^{1}$ 


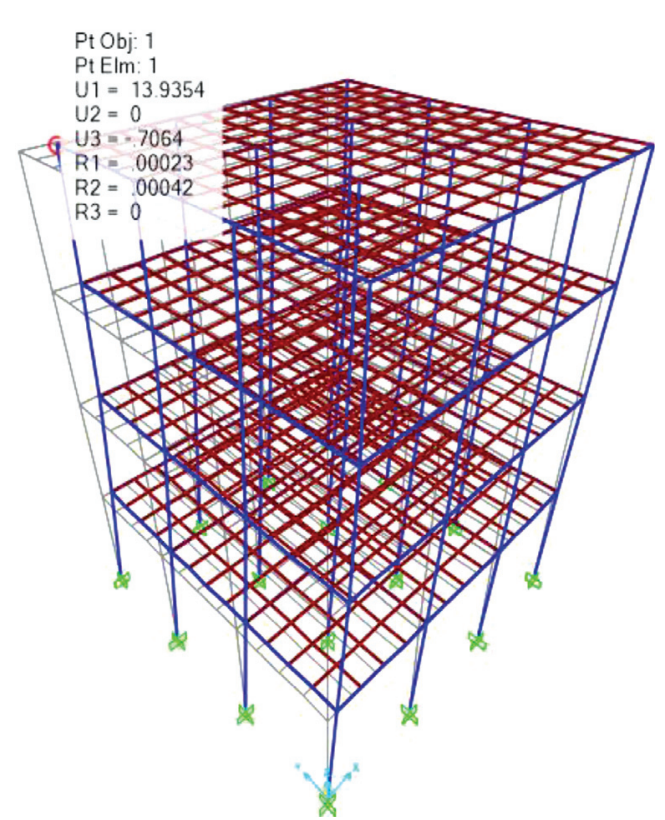

Figure 3: General model's displaced view after the loading

\subsection{Load conditions}

The calculations were done with three seismic-analysis methods including an equivalent static load, a modal analysis and time history. It was found that the maximum displacement values for the storeys occured during the analyses using the time-history method. Hence, the time-history method was chosen for the analysis. For the seismic load, the acceleration records of the 1999 Düzce Earthquake in the east-west direction were used. Figure 3 shows the displaced view of the general model after the loading.

\subsection{Storey displacements}

To get the limit values of the codes regarding the soft storey, eleven sub-models were designed. Lateral storey displacements of each model were obtained with SAP2000 and tabulated for the calculations of storey rigidities.

\section{CALCULATIONS AND RESULTS}

\subsection{Calculations according to the Turkish Seismic Code (TSC 2007)}

With respect to the TSC 2007, the soft-storey irregularity plays an important role when choosing the seismic-analysis method different from the other modern countries' codes. The soft-storey conditions from the TSC 2007 are expressed with Equations (1) and (2):

$\eta_{\mathrm{ki}}=\left(\Delta_{i} / h_{i}\right)_{\mathrm{avg}} /\left(\Delta_{i+1} / h_{i+1}\right)_{\mathrm{avg}}>2.0 \rightarrow$ Soft Storey

$\eta_{k i}=\left(\Delta_{i} / h_{i}\right)_{\mathrm{avg}} /\left(\Delta_{i-1} / h_{i-1}\right)_{\mathrm{avg}}>2.0 \rightarrow$ Soft Storey

where $\Delta$ is the storey displacement, and $h$ is the storey height. ${ }^{10}$

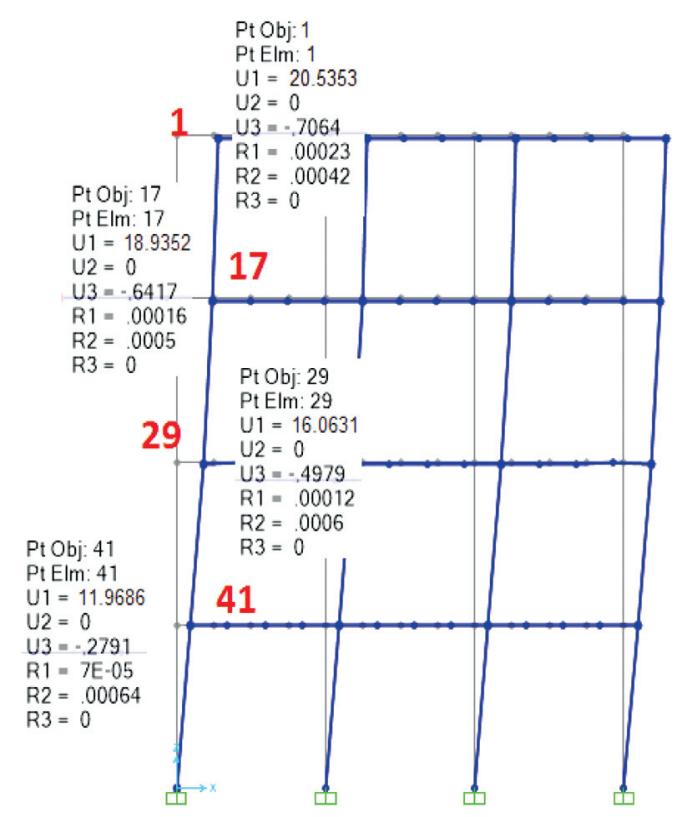

Figure 4: Joint displacements of Model 8

According to the storey-displacement values obtained with the analyses, Equations (1) and (2) were applied and the critical first-storey height was determined. With regard to the calculations, Model 8 was found to have the critical height of the soft-storey formation of $4.35 \mathrm{~m}$. Figure 4 shows joint displacements of Model 8 .

Lateral-displacement values for Model 8 are tabulated in Table 3.

Table 3: Displacement values for Model 8

\begin{tabular}{|c|c|}
\hline \multicolumn{2}{|c|}{$h=4.35 \mathrm{~m}$} \\
\hline Joint & $\begin{array}{c}\text { Displacement-x } \\
(\mathrm{mm})\end{array}$ \\
\hline 41 & 11.97 \\
\hline 29 & 16.06 \\
\hline 17 & 18.94 \\
\hline 1 & 20.54 \\
\hline
\end{tabular}

The calculation for Model 8 is shown in Equation (3):

$$
h_{k 1}=\frac{\frac{\Delta_{1}}{h_{1}}}{\frac{\Delta_{2}}{h_{2}}}=\frac{\frac{11.97}{4.35}}{\frac{(16.06-11.97)}{3}}
$$

$\eta_{\mathrm{k} 1}=2.02>2.0 \rightarrow$ Critical - Soft storey formation with a minor difference

In Table 4, the results of all the models are given. Based on the observations of all the calculations, we can say that the soft-storey irregularity was first formed in Model 8 and then in the other models where the firststorey height was more than $4.35 \mathrm{~m}$. The value of $\eta_{\mathrm{ki}}=$ $2.032>2.0$ was confirmed to be the critical value of the soft-storey formation according to the TSC 2007. In other words, the minimum height of the first storey, 
which made this building form a soft storey with respect to the TSC 2007, was $4.35 \mathrm{~m}$.

Table 4: Models' soft-storey-irregularity situations according to TSC 2007

\begin{tabular}{|c|c|c|c|}
\hline $\begin{array}{c}\text { Model } \\
\text { number }\end{array}$ & $\begin{array}{c}h, \text { height of } \\
\text { the first storey } \\
(\mathrm{m})\end{array}$ & $\begin{array}{c}\eta_{\mathrm{ki}} \\
\text { (rigidity-irregularity } \\
\text { index })\end{array}$ & $\begin{array}{c}\text { Soft-storey } \\
\text { irregularity } \\
\text { situation }\end{array}$ \\
\hline 1 & 3.00 & $1.05<2.0$ & Regular \\
\hline 2 & 3.30 & $1.12<2.0$ & Regular \\
\hline 3 & 3.70 & $1.53<2.0$ & Regular \\
\hline 4 & 3.85 & $1.57<2.0$ & Regular \\
\hline 5 & 4.00 & $1.75<2.0$ & Regular \\
\hline 6 & 4.25 & $1.94<2.0$ & Regular \\
\hline 7 & 4.30 & $1.98<2.0$ & Regular \\
\hline 8 & 4.35 & $2.03>2.0$ & $\begin{array}{c}\text { Critical - } \\
\text { Irregular }\end{array}$ \\
\hline 9 & 4.40 & $2.05>2.0$ & Irregular \\
\hline 10 & 4.50 & $2.12>2.0$ & Irregular \\
\hline 11 & 5.00 & $2.48>2.0$ & Irregular \\
\hline
\end{tabular}

\subsection{Calculations according to the Indian and Ameri- can Seismic Codes (IS 1893-1, ASCE 7)}

The American Code (ASCE 7) and Indian Code (IS 1893-1) treat a lot of formulations and obligations regarding the soft-storey conditions in the same way.

These codes scrutinize the soft-storey issue for two cases. ${ }^{11,12}$

1. Normal Soft Storey: If a storey's lateral stiffness is less than $70 \%$ of the stiffness of the storey above it or less then $80 \%$ of the average stiffness of the above three storeyes, this storey is a soft storey.

2. Extreme Soft Storey: A storey's lateral stiffness is less then $60 \%$ of the above storey's stiffness or less then $70 \%$ of the average stiffness of the above three storeyes.

Equations (4) and (5) show the conditions of a softstorey formation.

$$
k_{\mathrm{i}}<0.7 \mathrm{k}_{\mathrm{i}+1} \rightarrow \text { Soft storey }
$$

or

$$
k_{\mathrm{i}}<0.8\left(\frac{k_{i+1}+k_{i+2}+k_{i+3}}{3}\right) \rightarrow \text { Soft storey }
$$

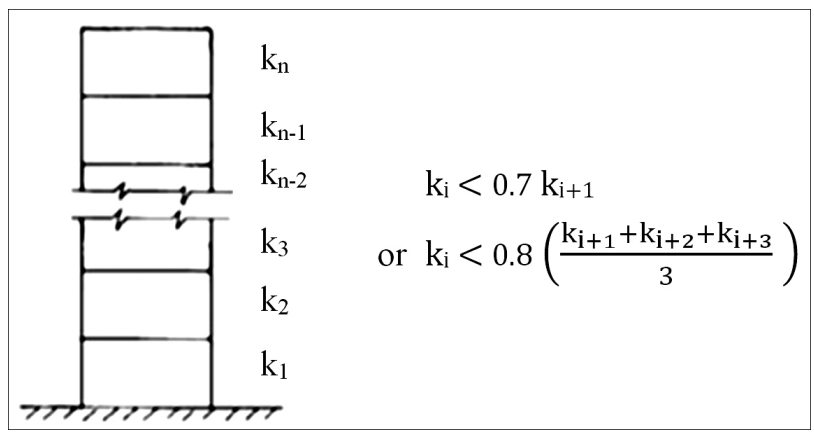

Figure 5: Condition for a soft storey ${ }^{12}$ where $k$ is the lateral-storey stiffness. ${ }^{11,12}$ To find storey stiffness $k$, Equation (6) is used.

$$
F=k \times u
$$

where $F$ is the storey's equivalent static seismic load and $u$ is the lateral displacement value in the seismic direction. The condition for the formation of a soft storey according to the ASCE/Indian codes is also given in Figure 5.

To obtain more realistic results and determine the equivalent static seismic loads of the storeys, it is more appropriate to calculate the loads on the basis of the Indian equivalent static seismic load method. These calculations were done for eleven models. The results of the analyses showed that Model 10 was the critical model according to the Indian Seismic Code. The first-storey height of this model was $h=4.50 \mathrm{~m}$. The lateral-displacement values for Model 10 are given in Table 5.

Table 5: Displacement values for Model 10

\begin{tabular}{|c|c|}
\hline \multicolumn{2}{|c|}{$h=4.50 \mathrm{~m}$} \\
\hline Joint & $\begin{array}{c}\text { Displacement-x } \\
(\mathrm{mm})\end{array}$ \\
\hline 41 & 13.30 \\
\hline 29 & 16.91 \\
\hline 17 & 20.25 \\
\hline 1 & 21.91 \\
\hline
\end{tabular}

The calculations of the equivalent static seismic load and lateral-acceleration spectrum were done using Equations (7) and (8), respectively.

$$
\begin{gathered}
V_{\mathrm{B}}=A_{\mathrm{h}} \times W \\
A_{\mathrm{h}}=\frac{Z I S_{\mathrm{a}}}{2 R g}
\end{gathered}
$$

where $V_{\mathrm{B}}$ is the total equivalent static seismic load, $A_{\mathrm{h}}$ is the lateral acceleration spectrum and $W$ is the total weight of the building in Equation (7). In Equation (8), $Z$ is the seismic zone (from the table), $I$ is the building importance factor (from the table), $R$ is the response reduction factor (from the table) and $S_{\mathrm{a}} / g$ is the average response-acceleration coefficient. ${ }^{12}$

The calculation formula for the equivalent static seismic load applying to any storey is given in Equation (9).

$$
Q_{i}=V_{B} \frac{w_{i} h_{i}^{2}}{\sum_{j=1}^{n} w_{j} h_{h}^{2}}
$$

The natural-period calculation for RC-frame buildings is done with Equation (10) where $h$ is the building's total height in meters.

$$
T_{\mathrm{a}}=0.075 h^{0.75}
$$

The above equations were applied to all the models and the calculations for the critical one (Model 10) are given below. 
$Q_{1}=777.3 \times \frac{1430.2 \times 4.50^{2}}{3 \times\left(1250.6 \times 3^{2}\right)+1430.2 \times 4.50^{2}}=138.9 \mathrm{kN}$

$Q_{2}=777.3 \times \frac{1250.6 \times 3^{2}}{3 \times\left(1250.6 \times 3^{2}\right)+1430.2 \times 4.50^{2}}=139.5 \mathrm{kN}$

$k_{1}=\frac{F}{u}=\frac{358.9}{13.2985}=26.99 \mathrm{kN} / \mathrm{mm}$

$k_{2}=\frac{F}{u}=\frac{139.5}{(16.9111-13.2985)}=38.61 \mathrm{kN} / \mathrm{mm}$

$26.99<0.7 \times 38.61=27.027 \rightarrow$ Critical - Soft storey formation with a minor difference

In Table 6, soft-storey results for all the storeys are given. The outcomes of the analyses show that Model 10 is the critical one according to the Indian Seismic Code. It was found that the models with a first-storey height of $4.50 \mathrm{~m}$ or more exhibited a soft-storey irregularity.

Table 6: Models' soft-storey-irregularity situations according to Indian Seismic Code (IS 1893-1)

\begin{tabular}{|c|c|c|c|}
\hline $\begin{array}{c}\text { Model } \\
\text { number }\end{array}$ & $\begin{array}{c}h, \text { height } \\
(\mathrm{m})\end{array}$ & $\begin{array}{c}k_{1} / k_{2} \text { (Storeys' } \\
\text { rigidity ratio) }\end{array}$ & $\begin{array}{c}\text { Soft-storey-irreg } \\
\text { ularity situation }\end{array}$ \\
\hline 1 & 3.00 & $0.90>0.7$ & Regular \\
\hline 2 & 3.30 & $0.86>0.7$ & Regular \\
\hline 3 & 3.70 & $0.81>0.7$ & Regular \\
\hline 4 & 3.85 & $0.79>0.7$ & Regular \\
\hline 5 & 4.00 & $0.77>0.7$ & Regular \\
\hline 6 & 4.25 & $0.74>0.7$ & Regular \\
\hline 7 & 4.30 & $0.73>0.7$ & Regular \\
\hline 8 & 4.35 & $0.72>0.7$ & Regular \\
\hline 9 & 4.40 & $0.71>0.7$ & Regular \\
\hline 10 & 4.50 & $0.69<0.7$ & $\begin{array}{c}\text { Critical }- \\
\text { Irregular }\end{array}$ \\
\hline 11 & 5.00 & $0.63<0.7$ & Irregular \\
\hline
\end{tabular}

\subsection{Calculations according to the Japanese Seismic Code}

The Japanese Seismic Code determines the soft-storey irregularity using a much more different approach, as shown below.

$R_{\mathrm{s}}=\frac{r_{\mathrm{s}}}{\bar{r}_{\mathrm{s}}}, R_{\mathrm{s}}<0.6 \rightarrow$ Soft storey

where $R_{\mathrm{S}}$ is the lateral-stiffness ratio and $r_{\mathrm{S}}$ is the lateral stiffness. The lateral stiffness is defined as the storey height divided by the storey drift caused by the lateral seismic shear for moderate earthquake motions. $\bar{r}_{\mathrm{s}}$ is the avearage lateral storey stiffness. ${ }^{13}$

Table 7: Displacement values for Model 2

\begin{tabular}{|c|c|}
\hline \multicolumn{2}{|c|}{$h=3.30 \mathrm{~m}$} \\
\hline Joint & Displacement-x $(\mathrm{mm})$ \\
\hline 41 & 6.12 \\
\hline 29 & 11.11 \\
\hline 17 & 14.39 \\
\hline 1 & 16.32 \\
\hline
\end{tabular}

In the results of the analyses, Model 2 was determined as the critical one according to the Japanese Seismic Code. This model's first-storey height was 3.30 $\mathrm{m}$. The resulting displacement values for Model 2 are given in Table 7.

Calculations were done for all the models and the solution for Model 2 is given below:

$r_{\mathrm{s} 1}=\frac{h}{\Delta}=\frac{3.3}{6.12}=0.54 \mathrm{~m} / \mathrm{mm}$

$r_{\mathrm{s} 2}=\frac{h}{\Delta}=\frac{3}{(11.11-6.12)}=0.60 \mathrm{~m} / \mathrm{mm}$

$r_{\mathrm{s} 3}=\frac{h}{\Delta}=\frac{3}{(14.39-11.11)}=0.92 \mathrm{~m} / \mathrm{mm}$

$r_{\mathrm{s} 4}=\frac{h}{\Delta}=\frac{3}{(16.32-14.39)}=1.55 \mathrm{~m} / \mathrm{mm}$

$\bar{r}_{\mathrm{s}}=\frac{r_{\mathrm{s} 1}+r_{\mathrm{s} 2}+r_{\mathrm{s} 3}+r_{\mathrm{s} 4}}{4}=\frac{0.54+0.60+0.92+1.55}{4}=$ $=0.902 \mathrm{~m} / \mathrm{mm}$

$R_{\mathrm{s}}=\frac{r_{\mathrm{s} 1}}{\bar{r}_{\mathrm{s} 1}}=\frac{0.54}{0.92}=0.599$

$0.599<0.6 \rightarrow$ Critical - Soft storey formation with a minor difference

Table 8 shows the soft-storey results for all the models. According to the Japanese Seismic Code, the critical model was Model 2 where the first-storey height was $3.30 \mathrm{~m}$.

Table 8: Models' soft-storey-irregularity situations according to Japanese Seismic Code

\begin{tabular}{|c|c|c|c|}
\hline $\begin{array}{c}\text { Model } \\
\text { number }\end{array}$ & $\begin{array}{c}h, \text { height } \\
(\mathrm{m})\end{array}$ & $\begin{array}{c}R_{\mathrm{s}} \text { (Lateral- } \\
\text { stiffness ratio) }\end{array}$ & $\begin{array}{c}\text { Soft-storey- } \\
\text { irregularity situation }\end{array}$ \\
\hline 1 & 3.00 & $0.654>0.6$ & Regular \\
\hline 2 & 3.30 & $0.599<0.6$ & Critical - Irregular \\
\hline 3 & 3.70 & $0.429<0.6$ & Irregular \\
\hline 4 & 3.85 & $0.416<0.6$ & Irregular \\
\hline 5 & 4.00 & $0.398<0.6$ & Irregular \\
\hline 6 & 4.25 & $0.370<0.6$ & Irregular \\
\hline 7 & 4.30 & $0.366<0.6$ & Irregular \\
\hline 8 & 4.35 & $0.362<0.6$ & Irregular \\
\hline 9 & 4.40 & $0.358<0.6$ & Irregular \\
\hline 10 & 4.50 & $0.350<0.6$ & Irregular \\
\hline 11 & 5.00 & $0.310<0.6$ & Irregular \\
\hline
\end{tabular}

\subsection{Soft-storey conditions from some other national building codes}

\section{Eurocode-8}

This code recommends an increase in the load-bearing capacities of columns to compensate for the rigidity loss due to the lack of infill walls in some storeys. The European Standard also states that even if there are the infill walls of a building's first storey and if the building is a residential one, there should be stirrups along all the first storey's columns, forming a stirrup-densification 
zone. This makes it possible to use the building as an office or to remove the infill walls. ${ }^{14,15}$

\section{Bulgarian Seismic Standard}

If the rigidity ratio of the adjacent storeys is less then $50 \%$, the less rigid storey is defined as a soft storey according to the Bulgarian Seismic Standard. It is advised that the seismic load affecting the soft storey should be calculated when determining the seismic-load design of a building. It is desired that a building with a soft storey should have a lateral-load capacity that is three times larger than the potential load. Apart from determining this situation, the standard does not make any other calculation suggestions. ${ }^{6}$

\section{New Zealand Seismic Code (NZS 4203:1992)}

The New Zealand Seismic Code states that to fulfil the vertical-regularity requirement, when using the equivalent static method, the lateral displacements of individual storeys should be reasonably close. ${ }^{16}$ However, it does not explain what reasonably close means.

\section{Israeli Seismic Standard (SI-413, 1995)}

When a storey's lateral stiffness is less then $65 \%$ of the above storey's stiffness or when a storey's lateral stiffness is less then $70 \%$ of the average stiffness of the above three storeys, a soft-storey irregularity occurs. ${ }^{17}$ The calculation of the stiffness is not explained in the standard.

\section{CONCLUSIONS}

In this study, the soft-storey irregularity, formed because of various reasons was investigated. Various national building codes were compared. Analytical comparisons were made between the Turkish Seismic Code (TSC 2007), American Code of Minimum Design Loads for Buildings and Other Structures (ASCE 7-2002), Indian Seismic Code (IS 1893-1, 2002) and Japanese Building Code. Additionally, some information was given about the soft-storey irregularity according to Eurocode-8, Bulgarian Seismic Standard, New Zealand Seismic Code and Israeli Seismic Standard. The analyses were done using the SAP2000 structural-analysis program. In this context, in a building model, which was symmetrical with respect to the plan dimensions, a softstorey irregularity was deliberately formed. Eleven submodels were formed by changing the general model's first-storey height to form different soft storeys. These models were completed and then compared according to the seismic codes' conditions and limiting values with regard to the soft-storey formation. In the eleven models, the storey heights were $3 \mathrm{~m}$, except for the first storey. All the other parameters were the same.

According to the results obtained, the following conclusions can be made:

With respect to the TSC 2007, the condition for a soft-storey formation is $n_{k i}>2.0$. The calculations showed that in Model 8, this parameter was exceeded with a minor difference of 2.035 and a soft-storey irregularity occured. For this model, the first-storey height was 4.35 meters.

As regards the Indian and ASCE Seismic Standards, the $k_{1} / k_{2}$ storey-stiffness ratio was at the limit value in Model 10. The ratio for this model was obtained as $k_{1} / k_{2}=0.699<0.7$ and so a soft-storey irregularity was formed. The first-storey height of Model 10 was $4.50 \mathrm{~m}$.

The calculations of the Japanese Seismic Code are very different from those of the other codes. When the results were examined, it was found that the $R_{\mathrm{s}}$ lateral-rigidity ratio was at the limit in the calculations for Model 2. In consequence, the $R_{\mathrm{s}}=0.599<0.6$ value made the first storey into a soft storey. For Model 2, the first-storey height was $h=3.30 \mathrm{~m}$.

When all the conclusions are considered, it is obvious that in the Japanese Seismic Code, the soft-storey phenomenon is handled much more carefully. With respect to this issue, the Japanese Code stays much more on the safe side in comparison with the other seismic codes. This can be thought of as reasonable if we think about the seismicity and soil conditions of Japan.

On the other hand, in the ASCE, Indian Seismic Code and Turkish Seismic Code, the soft-storey irregularity is generally tolerated. Also, in the Bulgarian, New Zealand and Israeli Seismic Codes, the soft storey is mentioned but these codes include no detailed numerical and analytical formulations or conditions regarding this critical issue. In these codes, the soft-storey conditions are more superficially treated.

The soft-storey irregularity, which causes great losses under the effect of a seismic load, should be determined with much more sensitive numerical calculation methods in the national seismic codes, especially in the earthquake-prone countries.

\section{REFERENCES}

${ }^{1}$ T. Sandikci, Investigation of relationship between soft story and torsional irregularities in reinforced concrete buildings, Master Thesis, Karadeniz Technical University, Trabzon 2014

${ }^{2} \mathrm{G}$. Işik, Investigation of short column and soft story behavior at reinforced concrete structures, Master Thesis, Karadeniz Technical University, Trabzon 2006

${ }^{3}$ C. Arnold, Designing for earthquakes: A manual for architects, Fema 454, Chapter 5, USA 2006

${ }^{4}$ S. G. Gök, Design of a multistorey reinforced concrete buiilding with A3 irregularity according to Turkish Eurocode and ACI 318 Regulations, Master Thesis, Istanbul Technical University, Istanbul 2013

${ }^{5} \mathrm{~T}$. Öztürk, Effect of openings in building slabs on the structural system behavior, TMMOB IMO Teknik Dergi, 24 (2013), 6233-6256

${ }^{6}$ H. B. Kaushik, D. C. Rai, S. K. Jain, Code approaches to seismic design of masonry-infilled reinforced concrete frames: A state-ofthe-art review, Earthquake Spectra, 22 (2006), 961-983, doi:10.1193/ 1.2360907

${ }^{7}$ F. Bahadir, F. S. Balik, Predicting displacement data of threedimensional reinforced concrete frames with different strengthening 


\section{S. DONDUREN, A. NAKIPOGLU: COMPARISON OF R/C BUILDINGS WITH A SOFT-STOREY ...}

applications using ANN, Periodica Polytechnica Civil Engineering, 61 (2017), 843-856, doi:10.3311/PPci.9652

${ }^{8}$ J. Komínek, M. Pohanka, Estimation of the number of forward time steps for the sequential Beck approach used for solving inverse heat-conduction problems, Materials and Technology, 50 (2016) 2, 207-210, doi:10.17222/mit.2014.192

${ }^{9}$ I. Nikolić, I. Janković - Častvan, J. Krivokapić, D. Đurović, V. Radmilović, V. Radmilović, Geopolymerization of low-grade bauxite, Materials and Technology, 48 (2014) 1, 39-44

${ }^{10}$ TSC 2007, Specification for structures to be built in disaster areas (Turkish seismic code 2007), The Turkish Ministry of Public Works and Settlement, Ankara

${ }^{11}$ ASCE 7-02, Minimum design loads for buildings and other structures, American Society of Civil Engineers, Virginia
${ }^{12}$ IS 1893-1:2002 Indian standard criteria for earthquake resistant design of structures - Part 1: General provisions and buildings (Fifth Revision), Bureau of Indian Standarts, New Delhi

${ }^{13} \mathrm{Y}$. Ishiyama, Intorduction to earthquake engineering and seismic codes in the world, Hokkaido 2011, 115

${ }^{14}$ EN 1998-1:2004 Eurocode 8: Design of structures for earthquake resistance - Part 1: General rules, seismic actions and rules for buildings, European Comittee for Standardization, Brussels

${ }^{15}$ S. A. Kaplan, Dolgu Duvarlarin Betonarme Taşiyici Sistem Performansina Etkisi, TMH, 452 (2008), 49-62

${ }^{16}$ NZS 4203:1992 General structural design and design loadings for buildings, Standards Association of New Zealand, Wellington

${ }^{17}$ SI 413:2009 Design provisions for earthquake resistance of structures, The Standards Institution of Israel, Tel Aviv 